\title{
Transformational leadership as a mediator in the relationship between satisfaction with remuneration and the retention of artisans in the military
}

\begin{tabular}{|c|c|}
\hline \multicolumn{2}{|c|}{$\begin{array}{l}\text { Authors: } \\
\text { Zamokuhle W. Shabane }{ }^{1} \\
\text { Cecile M. Schultz } \\
\text { Catharina E. van Hoek }\end{array}$} \\
\hline \multicolumn{2}{|c|}{$\begin{array}{l}\text { Affiliations: } \\
{ }^{1} \text { Department of Defence, } \\
\text { Pretoria, South Africa }\end{array}$} \\
\hline \multicolumn{2}{|c|}{$\begin{array}{l}{ }^{2} \text { Department of People } \\
\text { Management and } \\
\text { Development, Tshwane } \\
\text { University of Technology, } \\
\text { South Africa }\end{array}$} \\
\hline \multicolumn{2}{|c|}{$\begin{array}{l}\text { Corresponding author: } \\
\text { Zamokuhle Shabane, } \\
\text { shabanezw@yahoo.com }\end{array}$} \\
\hline \multicolumn{2}{|c|}{$\begin{array}{l}\text { Dates: } \\
\text { Received: } 06 \text { Mar. } 2017 \\
\text { Accepted: } 27 \text { Sept. } 2017 \\
\text { Published: } 28 \text { Nov. } 2017\end{array}$} \\
\hline \multicolumn{2}{|c|}{$\begin{array}{l}\text { How to cite this article: } \\
\text { Shabane, Z.W., Schultz, C.M., } \\
\text { \& Van Hoek, C.E. (2017). } \\
\text { Transformational leadership } \\
\text { as a mediator in the } \\
\text { relationship between } \\
\text { satisfaction with } \\
\text { remuneration and the } \\
\text { retention of artisans in the } \\
\text { military. SA Journal of Human } \\
\text { Resource Management/SA } \\
\text { Tydskrif vir } \\
\text { Menslikehulpbronbestuur, } \\
\text { 15(0), a923. https://doi. } \\
\text { org/10.4102/sajhrm. } \\
\text { v15i0.923 }\end{array}$} \\
\hline \multicolumn{2}{|c|}{$\begin{array}{l}\text { Copyright: } \\
\text { (C) 2017. The Authors. } \\
\text { Licensee: AOSIS. This work } \\
\text { is licensed under the } \\
\text { Creative Commons } \\
\text { Attribution License. }\end{array}$} \\
\hline \multicolumn{2}{|l|}{ Read online: } \\
\hline 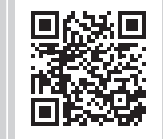 & $\begin{array}{l}\text { Scan this QR } \\
\text { code with your } \\
\text { smart phone or } \\
\text { mobile device } \\
\text { to read online. }\end{array}$ \\
\hline
\end{tabular}

\begin{abstract}
Orientation: The field of leadership has been extensively researched over the last couple of decades, with a particular emphasis on the different types of leadership styles. The most valuable resource that any manager works with is human resources. Studies have indicated that the way in which people are managed is influenced by the leadership styles of managers. This, in turn, influences employee behavioural intention, including intention to quit. Retention is, in turn, influenced by a number of factors, including remuneration. This study considers the relationship between satisfaction with remuneration and retention and the mediating role that a transformational leadership style may play in this regard.
\end{abstract}

Research purpose: The objectives of this study were twofold. Firstly, to determine whether transformational leadership played a mediating role in the relationship between satisfaction with remuneration and intention to stay amongst artisans employed in the military. Secondly, to determine whether there were demographic differences for these findings.

Motivation for the study: This study was conducted to determine whether a perceived lack or presence of transformational leadership influences the intention to quit amongst employees in relation to their level of satisfaction with their remuneration. In this way, the study may assist in determining strategies to improve artisan retention levels.

Research methodology: The study was quantitative in nature. A survey research design was applied to collect data, using a questionnaire as the survey instrument, from artisans $(N=108)$ employed at a military unit in Pretoria.

Main findings: The results revealed that the participants, regardless of gender or race, were generally unsatisfied with their remuneration. Transformational leadership was found to play a mediating role in the relationship between satisfaction with remuneration and intention to stay.

Practical/managerial implications: Organisations should develop the transformational leadership skills of their managers in order to increase talent retention levels and reduce employees' intentions to quit.

Contribution and value additions: The results of the study could assist military base commanders in improving artisan retention levels through implementing effective transformational leadership development programmes.

\section{Introduction}

Talent attraction and retention is a challenge for organisations across the world. The first step in the process of increasing employee retention is often the administration of a satisfaction survey that seeks to measure employee perceptions of retention strategies (Rust \& Pielack, 1996). Employee retention is defined as the development and implementation of integrated strategies or systems designed to increase workplace productivity by developing improved processes for attracting, developing, retaining and utilising people with the required skills and aptitude to meet current and future business needs. This can result in employees liking and identifying with their employer, and displaying commitment, trust and readiness to recommend them to other potential employees and clients (Sinha \& Sinha, 2012).

Transformational and charismatic leadership are highly associated with individual and organisational performance. The effectiveness of leaders is measured by their ability to provoke or lead followers towards a common or shared goal (Ahmad, Abbas, Latif \& Rasheed, 2014). Transformational leadership has the effect of 'transforming' followers' attitudes, beliefs and behaviours (Ehrich \& Ehrich, 2012). 
The focus of this study is to understand whether the absence or presence of transformational leadership has a mediating effect on artisans' level of satisfaction with remuneration and their intention to stay with or quit their employer.

\section{Purpose}

The objectives of this study are:

- to determine whether there are significant relationships between transformational leadership, retention and satisfaction with remuneration

- to determine whether transformational leadership is a mediator in the relationship between satisfaction with remuneration and retention

- to determine whether categories of artisan groups perceive transformational leadership, retention and satisfaction with remuneration differently.

\section{Literature review}

\section{Employee retention}

Employers seek to attract and retain talented employees. Before any employee may be acquired and retained by any organisation, he or she must possess the set of skills that no other person possesses or where it is difficult to recruit such a scarce-skilled employee. This is referred to as talent. Talent is defined as an individual's differentiated potential or ability to execute his or her functions and duties against the organisation's growth strategy (Botha, Bussin \& De Swardt, 2011).

Employee retention is defined as a process that ensures that the organisation at all times has access to human capital capacity (competence, capability), including leadership, to execute its business strategy and operations effectively and efficiently, both now and in the future (Bussin, 2014). The author emphasises the importance of talent management as a retention strategy to ensure the continuous supply of the necessary workplace skills in a rapidly changing work environment.

Talent and talent management are directly linked to the ability of an organisation to attract, acquire, manage and retain personnel for longer, thus maximising profit and achieving the organisational vision (Bussin, 2014). Employee retention refers to the efforts by an organisation to keep in employment those employees of whom the organisation has a positive evaluation and who would normally only leave the organisation through voluntary resignation (Van Rooyen, Du Toit, Botha \& Rothmann, 2010).

Despite South Africa's potential to compete globally, numerous challenges remain. Skills shortages have a negative effect on the availability of competent people in the country (Van Schalkwyk, Du Toit, Bothma \& Rothmann, 2010). In particular, there is a critical shortage of artisans in South Africa (Van Rooyen et al., 2010) and artisan retention is thus a particular challenge. The artisan is described as a highly skilled person working with hands, with emphasis on practical skills in a technical field that are manual in nature. They include trades such as millwright, electrician, plumber, boilermaker, mechanic, patternmaker and injection moulder, welder, fitter, turner, sheet metal worker, mechatronics, toolmaker, patternmaker, bricklayer, carpenter, joiner, shutter hand, steel fixers, glaziers, plasterer, tillers, sound technician and instrumentation and electronics technician (Jordaan \& Barry, 2009; The Skills Portal, 2017a).

Artisan retention is of key importance not only because the country is facing a critical shortage of artisans, but also because the average age of an artisan is of concern. In a study conducted by Jordaan and Barry in 2009, this age was 54 years (Jordaan \& Barry, 2009). Therefore, $70 \%$ of the artisans who were employed at the time of Jordaan and Barry's research would have exited the labour force within 5-6 years after their research, which would only have aggravated the shortage of artisans and intensified the competition for talent. Organisations will have to implement strategies to keep artisans in their service. Van Rooyen et al. (2010) report that many artisans are being recruited intensively by Canada and Australia, which has led to local organisations trying to counter this by offering more competitive salaries and retention bonuses.

\section{Factors contributing to employee retention}

In their study, 'Employee satisfaction, entrepreneurship and firm growth: A model', Antoncic and Antoncic (2011) identified the factors listed below as having a crucial role in increasing employee satisfaction and ensuring high employee retention.

\section{General satisfaction}

According to Antoncic and Antoncic (2011), general satisfaction pertains to employees who are relatively well rewarded financially for their work, and find their work challenging, exciting and providing them with a sense of accomplishment. These employees are committed to the organisation, feel a great sense of personal satisfaction and are proud to tell others that they are part of their organisation. General satisfaction is further characterised by an organisation in which most employees are very satisfied with their job, feel that they have the opportunity to be independent through their actions in their positions and feel the prestige of their position inside the company.

\section{Employee relationships}

Antoncic and Antoncic (2011) further outline that the employee relationships, which occur when employees feel that their colleagues are kind to them, get along with them and stimulate them, have an influence on job satisfaction and retention. This can be enhanced by the company's efforts to manage the relationship between themselves and employees, and by providing fair and consistent treatment to all employees (Study.com, 2017).

\section{Employee loyalty}

Employee loyalty occurs when employees are not actively searching for alternative employment and are not responsive 
to offers (K@W, 2012). Employee loyalty is found when employees are able to talk about their organisation to their friends, and portray it as a great organisation to work for (Antoncic and Antoncic, 2011)

\section{Remuneration}

Schlechter, Hung and Bussin (2014) stress the point that the money consists of three components, namely affective, symbolic and behavioural components.

The affective component suggests that on one end of a continuum, there are some people who view money as important and valuable, whilst on the other end, some people perceive the value of money as bad and evil. Symbolically, money is associated with attributes that most people strive for. These include achievement and recognition, status and respect, freedom and control and power. Money is often used to recognise accomplishments; it can provide the luxury of time and autonomy as well as power and access to resources. The behavioural component focuses on people's actions such as investing money, concludes Schlechter et al. (2014):

From the employer's point of view, pay is a powerful tool for furthering the organisation's strategic goals. Firstly, pay has a large impact on employee attitude and behaviour. It influences what kind of employees are attracted to the organisation and remain and it helps in aligning their interests with those of the company. (Noe et al., 2015, p. 25)

Table 1 illustrates the phases of rewards.

\section{Factors mediating the role between retention and satisfaction with remuneration}

There are many factors that could play a mediating role in the relationship between retention and satisfaction with remuneration. Coomber and Barriball (2006) outline a few factors below:

- Economic factors: They include sub-factors such as pay or remuneration, job market and training provided by the employer.

TABLE 1: Phases of rewards.

\begin{tabular}{ll}
\hline The modalities of reward & Specific descriptions \\
\hline Wage & $\begin{array}{l}\text { A wage is usually a financial compensation, received by } \\
\text { employees in exchange for their labour. }\end{array}$ \\
& $\begin{array}{l}\text { A salary is a form of periodic payment from an } \\
\text { employer to an employee, which may be specified in an } \\
\text { employment contract. It is contrasted with piece wages, } \\
\text { where each job, hour or other unit is paid separately, } \\
\text { rather than on a periodic basis. }\end{array}$ \\
& $\begin{array}{l}\text { Compensation is something similar with pay or salary, } \\
\text { typically a monetary payment for services rendered, as } \\
\text { in an employment. Some benefits may be concluded. }\end{array}$ \\
Total compensation & $\begin{array}{l}\text { Total compensation includes pay, benefits, flexible } \\
\text { schedules, education assistance, training courses and } \\
\text { workplace opportunities to help you get the most out } \\
\text { of your career and personal life. }\end{array}$ \\
Total reward & $\begin{array}{l}\text { Total reward covers all the elements that employees } \\
\text { value in working for their employer. It emphasises the } \\
\text { integrity of remuneration and is put forward in contrast } \\
\text { to total compensation. Although at most times, it is } \\
\text { thought as the same as total compensation, total } \\
\text { reward remains the most new word in the category of } \\
\text { remuneration or reward. }\end{array}$ \\
\hline
\end{tabular}

Source: Jiang, Z., Xiao, Q., Qi, H., \& Xiao, L. (2009). Total reward strategy: A human resources management strategy going with the trend of the times. International Journal of Business and Management, 4(11), 177-183. https://doi.org/10.5539/ijbm.v4n11p177
- Structural factors: Work environment and work context.

- Psychological factors: Individual characteristics and employee demographic and leadership.

Based on the above discussion, one of the most critical factors is psychological factor and it encompasses leadership, more specifically transformational leadership. This form of leadership is discussed next.

\section{Transformational leadership}

Transformational leadership is described as an ability to network and remain functionally separate from execution-focused elements of the organisation, for example, business units, divisions and departments (Deiser, 2012). Transformational leaders take personal and collective ownership for visioning the future state of the organisation and championing transformational change throughout the organisation (Deiser, 2012).

Deiser (2012) elaborates that transformational leaders demand much from their employers, such as freedom to create, make mistakes, learn, an unambiguous remit to drive transformation, a collaborative leadership ethos and access to diverse talent. They further expect clarity about the opportunity and potential for their contribution within the organisation, the opportunity to leave a positive and sustainable footprint, significant learning and development opportunities, as well as stimulation and challenge (intellectually and emotionally).

Transformational leadership is further defined by Van Zyl et al. (2013) as the ability of an individual to focus on transforming the organisation. These authors' focus is on the leader's accomplishments, and not on his or her personal characteristics or relationships with his or her followers. Northouse (2013) agrees with the argument by Van Zyl et al. (2013) but adds that transformational leadership is the process that transforms and changes people. Northouse (2013) says transformational leadership is concerned with emotion, values, ethics, standards and long-term goals. Transformational leadership also includes assessing followers' motives and intentions, satisfying their needs and treating them as full human beings.

Jeanine (2009) argues that transformational leaders strive to align their own interests and those of others with the interests of the group, organisation and society. Bass and Avolio (2004) add that transformational leaders are high on morals through their use of altruistic empowering strategies as a means of transforming followers' self-interest into collective values and interdependent goals that support organisational interests. Transformational leaders have been described as those who alter or manipulate the way their followers think about themselves such that feelings of commitment and involvement are enhanced (Brian, Gregory, Nathan \& Sean, 2011).

Transformational leadership may be perceived when a leader and a follower enable each other to advance to a 
higher level of morale and motivation (Nemanich \& Keller, 2007). Through the strength of their vision and personality, transformational leaders are able to inspire followers to change their expectations, perceptions and motivations and to work towards common goals. The evidence suggests that transformational leadership is linked to the outcomes that most organisations, individuals and leaders would value. Mokgolo, Mokgolo and Modiba (2012) found that engaging in transformational leadership behaviour is an effective strategy to empower line managers to meet the challenges they face.

Mokgolo et al. (2012) suggest that leaders must develop a vision that stakeholders share and to which they aspire, and that leaders should be able to use inspirational language in doing so. Leaders must engage in acts that involve personal risk and sacrifice. Furthermore, leaders must strive to gain the trust of subordinates and they must be role models and show total commitment to achieving the objectives of their organisation. The attributes of a transformational leader are depicted in Box 1.

It is clear, after considering all that is mentioned above, that transformational leadership is a non-self-serving action. It focuses on followers as the basic ingredients to achieve great success, and the well-being of followers is a priority for transformational leaders. Followers must do what they do voluntarily and willingly, regardless of the presence or absence of rewards and punishment.

\section{Research methodology Research design and approach}

The study was quantitative in nature and a questionnaire was used as the data collection instrument. Bless, HigsonSmith and Sithole (2014) state that a quantitative research design provides a detailed outline for the testing of the hypothesis, spelled out in clear and definite terms. Quantitative research is focused predominantly on collecting numerical data, and quite often relies on deductive reasoning, to form a view about the likelihood of an event occurring and its nature, and then tests whether the view is correct, partially correct or incorrect (Mncwabe, 2013). Therefore, a quantitative research approach was chosen as the most appropriate technique for this study.

This project could also be typified as a correlational study. Bless et al. (2014) believe that correlational research is used when a researcher can make a statement or hypothesis predicting the relationship between two or more variables.

BOX 1: Transformational leadership attributes.

\section{Functional attributes \\ Idealised influence or charisma \\ Inspirational motivation \\ Intellectual stimulation \\ Individualised consideration}

Source: Gregory, A., Stone, R.F., \& Patterson, R.K. (2004). Transformational versus servan leadership: A difference in leader focus. Leadership \& Organization Development Journal, 25(4), 349-361. https://doi.org/10.1108/01437730410538671
The results obtained will be able to provide a precise description of reality. Therefore, the survey design was correlational as it sought to measure the relationships between three variables (namely transformational leadership, employee retention and satisfaction with remuneration). A cross-sectional design was used to gather the data in order to achieve the specific aims of this study.

\section{Measuring instruments}

The measuring scales used in the questionnaire were developed by combining questions from three existing questionnaires. The adapted questionnaire was divided into four sections, namely demographical information, satisfaction with pay, transformational leadership and employee retention.

The first questionnaire used to source questions was the Minnesota Satisfaction Questionnaire, which was developed in 1967 by the Department of Vocational Psychology Research at the University of Minnesota (see Martins \& Proença, 2012). The questionnaire measures the level of all aspects of satisfaction in the workplace (Martins \& Proença, 2012). Of 100 questions measuring employees' satisfaction with their supervisors' leadership styles, working conditions, remuneration, development, employee relations and more, seven questions related to remuneration were extracted and derived from the themes identified in the literature review. The scale was developed as a unidimensional measure of the respondents' satisfaction with remuneration. In order to investigate the unidimensionality of the adapted scale, a factor analysis was performed. Kaizer-Meyer-Olkin (KMO) and Bartlett's test were used and a result of 0.753 was achieved, which is acceptable for sampling adequacy, as concluded by Kaiser (1970). Bartlett's test of sphericity (Kaiser, 1970) was significant at $p=0.000$.

The Transformational Leadership Questionnaire (Bass \& Avolio, 2004; Lievens, Van Geit \& Coetsier, 1997) was the second questionnaire with 22 questions related to transformational leadership, and factor analysis was conducted to ensure its validity. The questionnaire was a combination of information from Bass and Avolio (2004) and Lievens et al. (1997), where transformational leadership was measured based on how leaders think, treat followers, advance the careers of subordinates, develop followers and manage performance of followers and so on. Four sub-factors (Bass \& Avolio, 2004; Lievens et al., 1997) were extracted:

- Sub-factor 1: Idealised influence or charisma.

- Sub-factor 2: Intellectual stimulation.

- Sub-factor 3: Individualised consideration.

- Sub-factor 4: Inspirational leadership.

The third scale was developed with questions sourced from Sinha and Sinha (2012, pp.153-154) and consisted of 10 questions designed to measure the retention intentions of employees through identifying critical aspects of organisational actions that employees deem necessary for them to remain in the employ of the organisation. The scale measures aspects such as the employer's flexibility, working 
times, fringe benefits as well as compensation in general. All 10 questions focus on the reasons why employees are prepared to leave or stay in the organisation based on the presence or absence of transformational leadership.

Upon conducting factor analysis, two sub-factors emerged from the 10 questions, namely motivation and supervisor relationship as well as compensation and benefits. The initial principle components analysis showed that two factors reached an eigenvalue of more than 1 . A total of $59.08 \%$ of variance was explained by these two factors.

The reliability of these factors was investigated by means of Cronbach's alpha. The value was 0.762 , which was acceptable. According to Bryman and Bell (2007), Cronbach's alpha values of 0.70 and above are typically employed as a rule of thumb to denote a good level of internal reliability. Clark and Watson (1995) suggest that the average inter-item correlation of items should be between 0.1 and 0.5 . In this case, the value was 0.306. The employee retention scale may thus be regarded as valid and reliable, although it did not follow the original scale structure. The reliability of the two factors was also determined. Reliability was guaranteed by determining the Cronbach's alpha for sub-factor 1 , which was 0.869 and the average inter-item correlation was 0.475 , whilst for subfactor 2 and sub-factor 3, it was 0.804 and for sub-factor 4 it was 0.578 .

\section{Participants}

The population comprised 275 artisans in the military unit. A purposive sampling method was used. A total of 108 questionnaires were completed and returned, representing a $56.8 \%$ response rate, which was found to be acceptable (Bless et al., 2014). A representative sample could also be confirmed on account of the diverse nature of the respondents in terms of age, trade, employment length, service period, academic qualifications as well as ranks.

Of the 105 respondents who indicated their gender, 73 (69.5\%) were male respondents and 32 (30.5\%) female respondents. The youngest respondent was 20 years old and the oldest was 57 years old. The average age of the sample was 37.1 years. This indicates a largely male and relatively young group of respondents.

\section{Analysis}

A correlation analysis using Spearman's rho correlation (Bless et al., 2014) was conducted to determine the relationship between transformational leadership, satisfaction with remuneration and retention. Regression analysis was used to determine whether leadership is a mediator between employee's retention and satisfaction with remuneration.

\section{Results and discussion}

The study was directed at qualified artisans and apprentices (student artisans). The study also focused on different trades within the technical mustering. The average response per sub-factor from all respondents was 3, which is moderate, as shown in Figure 1.

\section{Categories of trade in the sample}

Diesel mechanics dominated the artisans' trade at 51 (47.2\%), followed by other trades at $22(20.4 \%)$. The minority comprised refrigerator mechanics with 2 (1.9\%). The occupational classes consisted of $79(73.1 \%)$ artisans and 28 $(25.9 \%)$ apprentices. The service length was evenly distributed from 1 to 35 years. Most respondents had at least 4 and 5 years' service, with the average years of service being 13.7 years. This may be indicative of a high labour turnover.

\section{Significant differences (trade)}

Analysis of variance was used to determine whether differences existed amongst different trade groupings of the population on their mean scores for each of the sub-factors identified above (Bless et al., 2014). The results of this analysis are presented in Table 2 .

\section{Analysis of variance}

This analysis revealed a significant difference in the population means of motor (diesel) mechanics, auto electricians, welders, refrigerator mechanics or carpenters as well as other trades as the probability value of $p=0.001$, which was less than 0.05 when it comes to satisfaction with remuneration.

On the basis of this finding, further statistical analysis, in the form of multiple correlations, was conducted to determine whether significant differences existed between the trade musterings for the sub-factor 'satisfaction with remuneration'. These results are presented in Table 3.

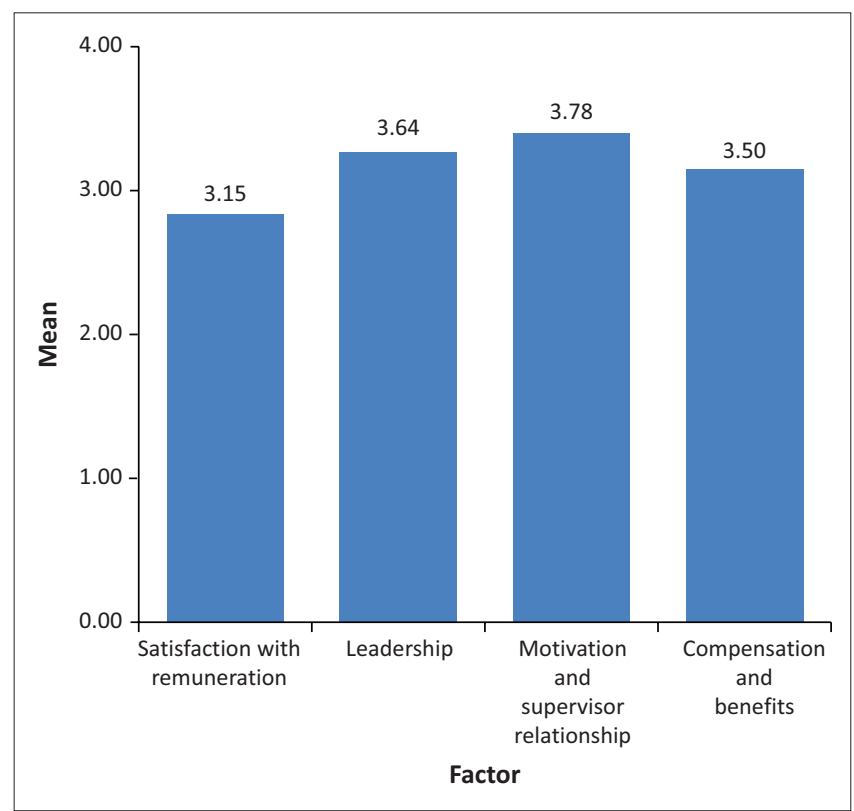

FIGURE 1: Descriptive statistics per factor. 
The results of this analysis revealed that the satisfaction with remuneration of diesel mechanics differed to that of welders, refrigerator mechanics, carpenters and other trades. In addition, this difference was also found to exist when comparing the latter group to diesel mechanics and auto electricians. These differences were found to be significant ( $p=0.002$ ). This seems to suggest that there are other factors influencing satisfaction with remuneration of diesel mechanics when compared to other trades.

TABLE 2: Analysis of variance comparison - between and within groups of motor (diesel) mechanics, auto electricians, welders or refrigerator mechanics or carpenters as well as other trades.

\begin{tabular}{lccccc}
\hline ANOVA & Sum of squares & $d f$ & Mean square & $\boldsymbol{F}$ & Sig. \\
\hline Satisfaction with remuneration & 7.48 & 2 & 3.740 & 7.026 & 0.00 \\
Between groups & 55.89 & 105 & 0.530 & - & - \\
Within groups & $\mathbf{6 3 . 3 7}$ & 107 & - & - & - \\
Total & & & & & \\
Transformational leadership & & & & & \\
Between groups & 2.28 & 2 & 1.140 & 2.480 & 0.08 \\
Within groups & 48.28 & 105 & 0.460 & - & - \\
Total & $\mathbf{5 0 . 5 7}$ & 107 & - & - & - \\
Motivation and supervisor relationship & & & & \\
Between groups & 0.84 & 2 & 0.420 & 0.880 & 0.41 \\
Within groups & 50.03 & 105 & 0.477 & - & - \\
Total & $\mathbf{5 0 . 8 7}$ & $\mathbf{1 0 7}$ & - & - & - \\
Compensation and benefits & & & & & \\
Between groups & 3.75 & 2 & 1.879 & 2.570 & 0.08 \\
Within groups & 76.57 & 105 & 0.729 & - & - \\
Total & $\mathbf{8 0 . 3 3}$ & $\mathbf{1 0 7}$ & - & - & - \\
\hline
\end{tabular}

ANOVA, analysis of variance.

TABLE 3: Multiple comparison tests between the mustering codes groups (post hoc).

\begin{tabular}{|c|c|c|c|c|c|}
\hline \multirow[t]{2}{*}{$\begin{array}{l}\text { Satisfaction with } \\
\text { remuneration }\end{array}$} & \multirow{2}{*}{$\begin{array}{c}\text { Mean } \\
\text { difference } \\
(I-J)\end{array}$} & \multirow[t]{2}{*}{$\begin{array}{l}\text { Std. } \\
\text { error }\end{array}$} & \multirow[t]{2}{*}{ Sig. } & \multicolumn{2}{|c|}{$\begin{array}{l}95 \% \text { confidence } \\
\text { interval }\end{array}$} \\
\hline & & & & $\begin{array}{l}\text { Lower } \\
\text { bound }\end{array}$ & $\begin{array}{l}\text { Upper } \\
\text { bound }\end{array}$ \\
\hline \multicolumn{6}{|l|}{ Motor (diesel mechanic) } \\
\hline Auto electrician & -0.12 & 0.19 & 0.82 & -0.61 & 0.36 \\
\hline $\begin{array}{l}\text { Welder, refrigerator mechanic, } \\
\text { carpenter or other }\end{array}$ & -0.57 & 0.15 & 0.00 & -0.96 & 0.18 \\
\hline \multicolumn{6}{|l|}{ Auto electrician } \\
\hline Motor (diesel mechanic) & 0.12 & 0.19 & 0.821 & -0.36 & 0.61 \\
\hline $\begin{array}{l}\text { Welder, refrigerator mechanic, } \\
\text { carpenter or other }\end{array}$ & -0.45 & 0.20 & 0.09 & -0.96 & 0.05 \\
\hline \multicolumn{6}{|c|}{ Welder, refrigerator mechanic, carpenter or other } \\
\hline Motor (diesel mechanic) & 0.57 & 0.15 & 0.00 & 0.18 & 0.96 \\
\hline Auto electrician & 0.45 & 0.20 & 0.09 & -0.05 & 0.96 \\
\hline
\end{tabular}

Note: The bold values depict where significant differences were detected between population means.

\section{Correlations}

Cohen (1988) argues that correlations can vary in magnitude from -1 to 1 , with -1 indicating a perfect negative linear relationship (as one variable increases, the other decreases), 1 indicating a perfect positive linear relationship (as one variable increases, the other decreases and the inverse) and 0 indicating no linear relation between two variables. As statistical significance of this value is largely influenced by sample size, Cohen (1988) suggests that a correlation of 0.5 is large, 0.3 is moderate and 0.1 is small. Table 4 indicates the results obtained in performing correlations between the four sub-factors.

The correlation between transformational leadership and satisfaction with remuneration was found to be at 0.380 with a significance level of 0.01 .

The correlation between motivation and supervisor relationship and satisfaction with remuneration was found to be at 0.389 with the significance level set at 0.01 . These correlations translate to moderate correlations based on Cohen's (1988) guidelines.

The correlation between motivation and supervisor relationship and transformational leadership was found to be at 0.528 and the correlation between compensation and benefits and satisfaction with remuneration was found to be at 0.508 . Because any correlation that is greater than 0.5 is considered large, according to Cohen (1988), this correlation was classified as large correlation.

Lastly, the correlation between compensation and benefits and transformational leadership was found to be at 0.458 . This correlation was moderate. This means that when supervisors display a transformational leadership style, satisfaction with remuneration is likely to increase significantly and the motivation-supervisor relationship improves.

\section{Regression}

Regression is a technique use to predict the value of a dependent variable using one or more independent variables. There are two types of regression analysis, namely simple and multiple regressions. Simple regression involves two variables: dependent variable and independent variable.

TABLE 4: Correlations between all four sub-factors.

\begin{tabular}{|c|c|c|c|c|c|}
\hline Spearman's rho & Correlation & $\begin{array}{l}\text { Satisfaction with } \\
\text { remuneration }\end{array}$ & $\begin{array}{c}\text { Transformational } \\
\text { leadership }\end{array}$ & $\begin{array}{l}\text { Motivation and supervisor } \\
\text { relationship }\end{array}$ & $\begin{array}{c}\text { Compensation and } \\
\text { benefits }\end{array}$ \\
\hline \multirow{2}{*}{$\begin{array}{l}\text { Satisfaction with } \\
\text { remuneration }\end{array}$} & $R^{* *}$ & 1.00 & $0.38 * *$ & $0.38 * *$ & $0.50 * *$ \\
\hline & $p$ & - & 0.00 & 0.00 & 0.00 \\
\hline \multirow[t]{2}{*}{ Leadership } & $r$ & $0.38 * *$ & 1.00 & $0.52 * *$ & $0.45 * *$ \\
\hline & $p$ & 0.00 & - & 0.00 & 0.00 \\
\hline \multirow{2}{*}{$\begin{array}{l}\text { Motivation and } \\
\text { supervisor relationship }\end{array}$} & $r$ & $0.38 * *$ & $0.52^{* *}$ & 1.00 & $0.62 * *$ \\
\hline & $p$ & 0.00 & 0.00 & - & 0.00 \\
\hline \multirow{2}{*}{$\begin{array}{l}\text { Compensation and } \\
\text { benefits }\end{array}$} & $r$ & $0.50 * *$ & $0.45^{* *}$ & $0.62 * *$ & 1.00 \\
\hline & $p$ & 0.00 & 0.00 & 0.00 & - \\
\hline
\end{tabular}

Note: The bold values (1.00) depict a strong linear relationship between sub-factors.

$* *$, Correlation is significant at the 0.01 level $(2$-tailed $) ; * *, R$ represents a correlation efficient measuring the linear relationship. 
Multiple regressions involve many variables, one dependent variable and many independent variables (Tyrrel, 2009). In this study, simple regression between retention and leadership was used.

Hayes (2009) defines mediation as a sequence of causal relations by which $\mathrm{X}$ exerts its effect on $\mathrm{Y}$ by influencing intervening variables.

A regression analysis was conducted to determine the mediating influence of leadership between satisfaction with remuneration and retention. There are four steps in measuring the mediation by leadership between satisfaction with remuneration and retention. The variables that were measured are depicted below where $\mathrm{X}=$ Satisfaction with remuneration, $\mathrm{Y}=$ Retention and $\mathrm{M}=$ Leadership.

Figure 2 depicts the effect transformational leadership $\left(c^{\prime}\right)$ has on the relationship between satisfaction with remuneration $(x)$ and employee retention $(y)$. The effects are discussed in Figure 3.

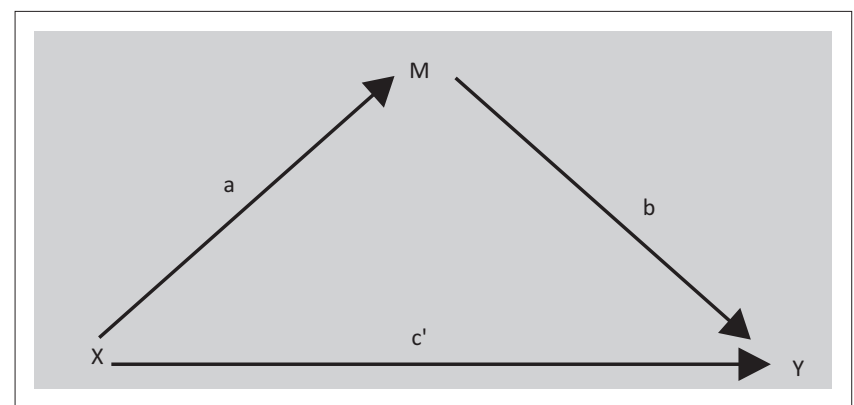

FIGURE 2: A simple mediation model effect.
Number of bootstrap samples for bias corrected bootstrap confidence intervals: 5000 and level of confidence for all confidence intervals in output: 0.95 .

Step 1: This step establishes the direct effect of $\mathrm{X}$ on $\mathrm{Y}$. In an intervening variable model, variable $X$ is postulated to exert an effect on an outcome variable $\mathrm{Y}$ through one or more intervening variables, sometimes called mediators. This represents path $\mathrm{c}$ in the model in Figure 2. In step 1 of the mediation model, the regression of satisfaction with remuneration on retention, ignoring the mediator, was significant $(b=0.4151, p=0.000)$.

Step 2: Next, it needs to be shown that the independent variable is correlated with the mediator. This step essentially involves treating the mediator as if it were an outcome variable and represents path a above. Step 2 showed that the regression of the satisfaction on the mediator, leadership, was also significant $(b=0.370, p=0.000)$.

Step 3: Now it must be demonstrated that the mediator affects the outcome variable (estimate and test path b). However, it needs to be controlled for the independent variable. In this case, the relationship between leadership and retention is significant $(b=0.463, p=0.000)$, controlling for satisfaction.

Step 4: To establish path $c^{\prime}$, namely that $M$ mediates the $X-Y$ relationship, the effect of $\mathrm{X}$ on $\mathrm{Y}$ controlling for $\mathrm{M}$ should be zero. This would mean that there is complete mediation. This analysis revealed that, controlling for the mediator (leadership), satisfaction with remuneration was still a significant predictor of retention $(b=0.244, p=0.000)$, which

\begin{tabular}{|c|c|c|c|c|c|c|c|}
\hline$R$ & \multicolumn{2}{|l|}{$R$-sq } & MSE & $F$ & $d f 1$ & $d f 2$ & $p$ \\
\hline 0.4149 & \multicolumn{2}{|l|}{0.17} & \multicolumn{2}{|r|}{220374} & 10000 & 1060000 & 0.00 \\
\hline \multicolumn{8}{|l|}{ Model } \\
\hline & \multicolumn{2}{|l|}{ coeff } & SE & $t$ & $p$ & $\mathrm{LLCl}$ & ULCI \\
\hline Constant & \multicolumn{2}{|l|}{2.4682} & 0.25 & 96435 & 0.00 & 1.96 & 2.97 \\
\hline $\begin{array}{l}\text { Satisfaction with } \\
\text { remuneration }\end{array}$ & \multicolumn{2}{|l|}{0.37} & 0.07 & 46944 & 0.00 & 0.21 & 0.52 \\
\hline \multicolumn{8}{|c|}{ Retention model summary 1} \\
\hline$R$ & \multicolumn{2}{|l|}{$R$-sq } & MSE & $F$ & $d f 1$ & $d f 2$ & $p$ \\
\hline 0.6440 & \multicolumn{2}{|l|}{0.41} & \multirow[t]{2}{*}{0.26} & 37.19 & 2.00 & 105.00 & 0.00 \\
\hline \multicolumn{7}{|l|}{ Model } & \\
\hline & \multicolumn{2}{|l|}{ coeff } & SE & $t$ & $p$ & $\mathrm{LLCl}$ & ULCI \\
\hline Constant & \multicolumn{2}{|l|}{1.24} & 0.28 & 4.32 & 0.00 & 0.67 & 1.81 \\
\hline Leadership & \multicolumn{2}{|l|}{0.46} & 0.07 & 5.78 & 0.00 & 0.30 & 0.62 \\
\hline $\begin{array}{l}\text { Satisfaction with } \\
\text { remuneration }\end{array}$ & \multicolumn{2}{|l|}{0.24} & 0.07 & 3.41 & 0.00 & 0.10 & 0.38 \\
\hline Normal theory & indirect & effect & & & & & \\
\hline Effect & & SE & & & $p$ & & \\
\hline 0.1714 & & 0.04 & & 51 & 0.00 & & \\
\hline
\end{tabular}

Note: The bold values depict a strong effect of $x$ on $y$ between sub-factors.

FIGURE 3: Leadership mediation model. 
suggests partial mediation. Satisfying all four conditions provides evidence for complete mediation, whereas satisfying the first three conditions indicates partial mediation.

Put in another way, if the effect of $X$ on $Y$ is reduced when the mediator is included $\left(c^{\prime}<c\right)$, then the direct effect is said to be partially mediated. The B coefficient for $\mathrm{c}$ is 0.415 and for path $c^{\prime}$, it is 0.244 . The effect is thus reduced. This is confirmed by the indirect effect in the output. Zero does not fall within the confidence intervals of the Beta coefficient $\mathrm{BCi}=0738 ; 0.299$; therefore, mediation can be assumed.

A Sobel test was conducted and found significant with mediation $(z=3.614, p=0.0003)$. It was found that leadership mediated the relationship satisfaction with remuneration and retention. In essence, this implies that any changes in either improving or deterioration in transformational leadership will increase the level of artisans desire to remain in the organisation or leave, regardless of the improvement in the levels of remuneration.

\section{Limitations}

The following limitations were encountered in conducting this study:

- Some respondents who were identified as part of the sample were not available during the data collection phase as they were deployed for a period of 1 year to the Democratic Republic of Congo (DRC); thus, their opinions could not be obtained.

- The number of officers who responded was very small compared to the number of available officers in the unit and their response rate was not representative of their ranks within the unit and the South African (SA) Army as a whole as the proportionality was skewed.

- A number of respondents did not indicate their age and length of service in the SA Army.

\section{Recommendations}

Based on the study, the following recommendations are made in terms of enhancing the retention of artisans within the military services:

- The South African National Defence Force (SANDF) and the SA Army need to revise the remuneration policy taking into consideration the different rank groups as there was a discrepancy in the way participants felt about remuneration.

- The SA Army should consider recruiting more women into the technical service mustering in order to enhance government imperatives and inclusivity.

- The SA Army should consider recruiting or developing an adequate number of officers by equipping them with a qualification beyond Grade 12 (for instance, bachelor's degrees) as these qualifications equip senior leaders with strategic managerial and leadership skills.
- Working conditions should be improved. This could be done by revising policies and procedures involved when artisans perform their job. Artisans should be empowered to find and fix technical and mechanical faults instead of only being limited to find and replace faulty parts. The facilities, such as workshops and kitchens, need to be revamped to the acceptable standard and be furnished with modern technology. Workshops need to be upgraded with the latest industry technology in order to ensure that artisans gain the same level of experience as their counterparts in the private sector.

- The SA Army should consider revising the promotion policy, so that it would be performance-based, as opposed to seniority-based. This will encourage quality output amongst artisans rather than keeping the status $q u o$ and passing time until the next promotion.

- The SA Army, and particularly the unit concerned, should provide more training interventions aimed at transformational leadership development, as well as create more awareness of the influence of leadership on employee retention.

\section{Conclusion}

The main aim of this study was to determine whether transformational leadership is a mediator in the relationship between satisfaction with remuneration and retention amongst artisans. The results clearly indicated that there is significant mediation between satisfaction with remuneration and compensation and transformational leadership. The results of the study could assist military base commanders in improving artisan retention levels through implementing effective transformational leadership development programmes. Talent management is a comprehensive, multidimensional concept with a myriad of perceptions that influence its effectiveness. It holds the potential to influence talent retention amongst military artisans. The effect of work prospects and preferences on turnover intentions changes consistently, which implies that enriching artisans' expectations of a 'brighter tomorrow' in their jobs could improve the probability of retention.

\section{Acknowledgements Competing interests}

The authors declare that they have no financial or personal relationships that may have inappropriately influenced them in writing this article.

\section{Authors' contributions}

C.M.S. was the academic supervisor and was responsible for the design of the project. She also helped with the preparation of the manuscript. C.E.v.H. was the cosupervisor and was also responsible for the design of the project. Z.W.S. was responsible for the research and fieldwork and wrote this article. 


\section{References}

Ahmad, F., Abbas, T., Latif, S., \& Rasheed, A. (2014). Impact of transformational leadership on employee motivation in telecommunication sector. Journal of Management Policies and Practices, 2(2), 11-25.

Antoncic, J.A., \& Antoncic, B. (2011). Employee satisfaction, entrepreneurship and firm growth: A model. Industrial Management \& Data Systems, 111(4), 589-607. https://doi.org/10.1108/02635571111133560

Bass, B.M., \& Avolio, B.J. (2004). Transformational leadership: Multifactor Leadership Questionnaire. Mind Garden. Retrieved 05 April, 2015, from http://www. statisticssolutions.com/wp-content/uploads/wp-post-to-pdf-enhanced-cache/1/ statisticssolutions.com/wp-content/uploads/wp-
multifactor-leadership-questionnaire-mlq.pdf

Bless, C., Higson-Smith, C., \& Sithole, S.L. (2014). Fundamentals of social research methods: An African perspective (5th ed.). Cape Town: Juta.

Botha, A., Bussin, M., \& De Swardt, L. (2011). An employer brand predictive model for talent attraction and retention. South African Journal of Human Resource Management, 9(1), 1-12. https://doi.org/10.4102/sajhrm.v9i1.388

Brian, T., Gregory, K., Nathan, M., \& Sean, T. (2011). An exploration of perspective taking as an antecedent of transformational leadership behaviour. Leadership \& Organization Development Journal, 32(8), 807-816. https://doi.org/10.1108/ 01437731111183748

Bryman, A., \& Bell, E. (2007). Research methodology in a business and management context. Cape Town: Oxford University Press.

Bussin, M. (2014). Remuneration and talent management: Strategic compensation approaches for attracting, retaining and engaging talent. Cape Town: Knowledge Resources.

Clark, L.A., \& Watson, D. (1995). Constructing validity: Basic issues in objective scale development. Psychological Assessment, 7, 309-319. https://doi.org/10.1037/ development. Psych

Cohen, J. (1988). Statistical power analysis for the behavioural sciences. Orlando, FL: Academic.

Coomber, B., \& Barriball, K.L. (2006). Impact of job satisfaction components on intent to leave and turnover for hospital-based nurses: A review of the research literature, King's College London, London, UK. International Journal of Nursing Studies, 44(2), 297-314. https://doi.org/10.1016/j.ijnurstu.2006.02.004

Deiser, R. (2012). Building the towers of Babel? Developing Leaders: Executive Education in Practice, 9. Retrieved May 14, 2015, from https://www.jbs.cam.ac.uk/fileadmin/ user upload/faculty/downloads/trevor-jon-developing-transformationalleadership.pdf

Ehrich, L.B.J. \& Ehrich, L.C. (2012). Confucius as transformational leader: Lessons for ESL leadership. International Journal of Educational Management, 26(4), 391-402. https://doi.org/10.1108/09513541211227791

Gregory, A., Stone, R.F., \& Patterson, R.K. (2004). Transformational versus servant leadership: A difference in leader focus. Leadership \& Organization Development Journal, 25(4), 349-361. https://doi.org/10.1108/01437730410538671

Hayes, A.F. (2009). Beyond Baron and Kenny: Statistical mediation analysis in the new millennium. Communication Monographs, 76(4), 408-420. https://doi.org/ 10.1080/03637750903310360

Jeanine, P. (2009). Distinguishing between transformational and servant leadership. Leadership \& Organization Development Journal, 30(3), 274-291. https://doi. org/10.1108/01437730910949544

Jiang, Z., Xiao, Q., Qi, H., \& Xiao, L. (2009). Total reward strategy: A human resources management strategy going with the trend of the times. International Journal of
Business and Management, 4(11), 177-183. https://doi.org/10.5539/ijbm.v4n11p177

Jordaan, N., \& Barry, M.L. (2009). Investigating the reasons for lack of skilled artisans in South Africa: The perspective of artisans. South African Journal of Engineering, 20(1), 173-184.
Kaiser, H.F. (1970). A second generation little jiffy. Psychometrika, 35(4), 401-415. https://doi.org/10.1007/BF02291817

K@W. (2012). Declining employee loyalty: A casualty of a new workplace. Retrieved July 21, 2017, from www.knowledge.wharton.upenn.edu/article/decliningemployee-loyalty-a-casualty-of-the-workplace/

Lievens, F., Van Geit, P., \& Coetsier, P. (1997). Identification of transformational leadership qualities: An examination of potential biases. European Journal of Work and Organizational Psychology, 6(4), 415-430. https://doi.org/10.1080/ 135943297399015

Martins, H., \& Proença, T. (2012). Minnesota Satisfaction Questionnaire, psychometric properties and validation in a population of Portuguese hospital workers. FEP working paper no. 471. Retrieved April 12, 2016, from http://wps.fep.up.pt/wps/ wp471.pdf

Mncwabe, S.H.P. (2013). Staff recruitment and selection at a university of technology. Unpublished MTech dissertation. Tshwane University of Technology, Pretoria.

Mokgolo, M.M., Mokgolo, P., \& Modiba, M. (2012). Transformational leadership in the South African public service after the April 2009 national elections. South African Journal of Human Resource Management, 10(1), 1-9. https://doi.org/10.4102/ sajhrm.v10i1.334

Nemanich, L.A., \& Keller, R.T. (2007). Transformational leadership in an acquisition: A field of study of employees. Leadership Quarterly, 18, 49-68. https://doi. org/10.1016/j.leaqua.2006.11.003

Noe, R.A., Hollenbeck, J.R., Gerhat, B., \& Wright, P.M. (2015). Human resources management: Gaining a competitive advantage (9th ed.). Berkshire, UK: McGrawHill Education.

Northouse, P.G. (2013). Leadership theory and practice (6th ed.). Thousand Oaks, CA: Sage.

Rust, R.T., \& Pielack, S.H.M.D. (1996). The satisfaction and retention of frontline employees. International Journal of Service Industry Management, 7(5), 62-80. https://doi.org/10.1108/09564239610149966

Schlechter, A., Hung, A., \& Bussin, M. (2014). Understanding talent attraction: The influence of financial rewards elements on perceived job attractiveness. SA Journal of Human Resource Management, 12(1), 647-660. https://doi. org/10.4102/sajhrm.v12i1.647

Sinha, C., \& Sinha, R. (2012). Factors affecting employee retention: A comparative analysis of two organizations from heavy engineering industry. European Journal of Business and Management, 4(3), 145-162.

Study.com. (2017). What is employee relations?-Definition and concept. Retrieved July 21, 2017, from www.study.com/academy/lesson/what-is-employee-definationlesson-quiz.htm

The Skills Portal. (2017a). Engineering and Artisans. Retrieved July 21, 2017, from https://www.skillsportal.co.za/skills-portal-categories/training-trainingcategories/engineering-and-artisans

The Skills Portal. (2017b). Learning to be an artisan. Retrieved July 21, 2017, from https://www.skillsportal.co.za/content/learning-become-artisan

Tyrrel, S. (2009). SPSS: Stats practically short and simple. Sydney: Tyrrel \& Ventus.

Van Rooyen, L., Du Toit, D.H., Botha, E., \& Rothmann, S. (2010). Artisan retention in an organisation in South Africa. South-African Journal of Human Resource Management, 8(1), 1-8. https://doi.org/10.4102/sajhrm.v8i1.300

Van Schalkwyk, S., Du Toit, D.H., Bothma, A.S., \& Rothmann, S. (2010). Job insecurity, leadership empowerment behaviour, employee engagement and intention to leave in a petrochemical laboratory South-African Journal of Human Resource Management, 8(1), 1-7. https://doi.org/10.4102/sajhrm. v8i1.234

Van Zyl, E., Dalglish, C., Du Plessis, M., Lues, L., \& Pieterson, E. (2013). Leadership in the African context. Cape Town: Juta. 